\title{
MOTIVASI TENAGA PENGAJAR DI PEDALAMAN PAPUA DALAM MENGAJAR DAN MELANJUTKAN STUDI PADA JURUSAN PENDIDIKAN GURU SEKOLAH DASAR (SEBUAH KAJIAN FENOMENOLOGIS)
}

\author{
Agus Kichi Hermansyah* \\ Adi Sumarsono \\ Dewi Puji Rahayu \\ Fredy \\ Pendidikan Guru Sekolah Dasar, Fakultas Keguruan dan Ilmu Pendidikan, Universitas Musamus \\ Jl. Kamizaun Mopah Lama, Rimba Jaya, Merauke, Papua, Indonesia \\ *email: aguskichi@unmus.ac.id.
}

Artikel diterima: 18 Pebruari 2020; disetujui: 31 Mei 2020

\begin{abstract}
This research aims to study and analyze the phenomena of teacher motivation in teaching and continuing studies in Higher Education. This study used a qualitative phenomological approach, which involved as many as five participants from the teachers who continued their studies in the PGSD Department at Musamus University. The process of collecting data through interview and observation methods. The main motivational research results of teachers teaching largely because of motivation from outside, namely permanent employment and income, there is also an internal motivation that is serving the country, and awareness to contribute. Motivation for continuing studies is encouragement to adjust to government regulations. The factor of getting prosperity is the last motivation because there is awareness to serve as a teacher.
\end{abstract}

Keywords: motivation; teacher; elementary school.

\begin{abstract}
Abstrak: Penelitian ini bertujuan untuk mengkaji dan menganalisa fenomena motivasi tenaga pengajar dalam mengajar dan melanjutkan studi di Perguruan Tinggi. Penelitian ini menggunakan pendekatan kualitatif fenomenologis, yang melibatkan partisipan sebanyak lima orang guru yang melanjutkan studi di jurusan PGSD Universitas Musamus. Proses pengumpulan data melalui metode wawancara dan observasi. Hasil penelitian menunjukkan motivasi utama guru mengajar sebagian besar karena motivasi dari luar, yaitu pekerjaan tetap dan mendapatkan penghasilan; motivasi internal untuk mengabdi kepada negara serta kesadaran untuk berkontribusi. Motivasi melanjutkan studi meliputi dorongan penyesuaian dengan peraturan pemerintah. Faktor mendapatkan kesejahteraan menjadi motivasi terakhir karena terdapat kesadaran untuk mengabdi sebagai guru.
\end{abstract}

Kata kunci: motivasi; guru; sekolah dasar.

Pendidikan adalah salah satu pendukung pembangunan bangsa. Melalui pendidikan dapat dicapai sumber daya manusia yang produktif dan berwawasan luas. Ketercapaian pendidikan 
bukan hanya sebatas hasil belajar siswa. Lebih dari itu, proses yang dilaksanakan menjadi tolak ukur dalam penilaian akan kualitas pendidikan. Melalui proses belajar yang terstruktur, tenaga pengajar yang profesional serta kurikulum yang sesuai, dapat dijadikan rujukan akan berhasilnya pendidikan (Selvi, 2010). Kualitas guru yang dibutuhkan bukan hanya kuantitas yang banyak akan tetapi juga harus berkualitas baik.

Pemerataan pendidikan sudah dilakukan pemerintah mencapai ujung barat hingga ujung timur Negara Indonesia. Pendidikan yang dirasakan di Pulau Sumatera juga akan diajarkan sama di Pulau Papua. Penyeragaman keberadaan pendidikan di seluruh Indonesia terjadi mulai dari kota hingga pedalaman adalah tantangan yang harus dicapai sebagai perwujudan sila ke lima Pancasila yaitu keadilan bagi seluruh rakyat Indonesia. Tujuan Pendidikan Nasional sesuai bunyi UndangUndang No. 20 Tahun. 2003 tentang Sistem Pendidikan Nasional mengemukakan bahwa pendidikan berfungsi untuk mengembangkan kemampuan dan membentuk watak serta peradaban bangsa yang bermartabat dalam rangka mencerdaskan kehidupan bangsa. Pendidikan bertujuan untuk berkembangnya potensi peserta didik agar menjadi manusia yang beriman, bertaqwa kepada Tuhan yang Maha Esa, berakhlak mulia, sehat berilmu, cakap, kreatif, mandiri dan menjadi warga negara yang demokratis serta bertanggung jawab.

Penentu keberhasilan dari proses pembelajaran, selain dari input siswa, proses, juga dapat ditentukan dari aspek guru. Guru adalah sosok yang dikenal dengan profesi pengabdi. Hal ini tidak salah jika disebutkan bahwa guru merupakan pahlawan tanpa tanda jasa. Guru menunjukkan eksistensinya sejak dahulu dengan melahirkan para pahlawan dan pemimpin negara. Profesi guru dapat diakui sebagai profesi sejak diterbitkannya Undang-Undang Guru dan Dosen Nomor 14 Tahun 2005. Karakteristik setiap tenaga guru dalam mendedikasikan tugasnya dalam setiap mengajar berbeda-beda. Hal ini salah satunya dipengaruhi oleh motivasi yang dipunyai oleh setiap guru (Tembang, Sulton, \& Suharjo, 2017).

Berkaitan dengan implementasi kurikulum yang ada di sekolahpun, sebaiknya guru sudah memahami dan menjalankannya. Guru harus berupaya keras supaya dapat mengimplementasikan kurikulum secara bertahap dan berkelanjutan (Hurit \& Harmawati, 2019). Guru aktif berpartisipasi dalam menyusun kurikulum. Ikut andil dalam merumuskan kurikulum dapat memberikan perasaan memiliki kurikulum bukan hanya menjalankan kurikulum (Siram, 1995). Seorang guru dalam melaksanakan peran sebagai tenaga pengajar akan mempengaruhi keberadaan dan kondisi suatu penduduk pada daerah yang terpencil.

Pendidikan adalah sarana untuk meningkatkan kualitas kesejahteraan masyarakat yang pada akhirnya dapat mengantarkan bangsa dalam menggapai kemakmuran (Pambudi, 2017). Keberadaan dari tenaga pengajar diharapkan dapat memberikan perubahan yang signifikan dalam proses pembelajaran. Kesadaran dari semua lapisan yang menyatakan kompetensi seorang guru 
diperlukan untuk menghasilkan kualitas pendidikan yang lebih bermakna (Musanna, 2012). Kemajuan zaman dan lajunya arus informasi menjadi salah satu tantangan yang harus diikuti sebagai tenaga pengajar yang selalu memberikan informasi selain dari materi pelajaran yang sesuai dengan bidangnya. Hal inilah yang menyebabkan semakin banyaknya guru yang berusaha untuk meng-update dan meng-upgrade ilmu. Salah satu cara yang dapat digunakan untuk hal tersebut ialah dengan melanjutkan studi ke tingkat yang lebih tinggi.

Secara keadaan geografis, Provinsi Papua terdapat penyebutan antara kota dan pedalaman (Nggaruaka, Hermansyah, \& Sauhenda, 2019). Penyebutan kata pedalaman bukan bermakna mendeskriditkan suatu daerah, akan tetapi lebih menonjolkan letak daerah yang memang jauh dari pusat kota sesuai dengan Permendikbud No.34 Tahun 2012. Daerah inilah yang sangat memerlukan perhatian dalam pemerataan pembangunan. Akses yang jauh dari kota wilayah pedalaman sangat mengalami keterbatasan dalam transportasi, infrastruktur dan juga pendidikan. Khususnya di daerah pedalaman masih memerlukan tenaga pengajar untuk mau mengajar dan bertahan di daerahnya.

Seorang guru dalam melaksanakan profesinya harus ditunjang dengan penyesuaian kecanggihan teknologi yang ada. Peran guru di Indonesia harus mampu memberikan konstribusi positif dalam bidang pembangunan manusia. Dalam hal pembelajaran, konstribusi dapat melalui perbaikan proses salah satunya dapat memanfaatkan teknologi informasi dan komunikasi dalam pembelajaran (Rosyid, 2016). Melalui profesinya, guru bukan hanya menjelaskan materi secara turun temurun akan tetapi juga mengarahkan siswa dalam beradaptasi dengan kemajuan zaman. Untuk itulah seorang guru dalam melaksanakan tugasnya harus selalu menjaga mutu pendidikan.

Kata mutu merupakan tolak ukur dalam suatu kualitas. Pendidikan dikatakan bermutu jika guru yang mengajar berhasil mencapai tujuan-tujuan pembelajaran, dibanding dengan guru yang tidak berhasil mencapai tujuan pendidikan (Tilaar, 2012). Selain sebagai tenaga pengajar yang siap mendarmabaktikan hidupnya, peran guru juga mempunyai peran yang sangat pokok dalam pendidikan. Disamping itu, permasalahan yang dihadapi guru masih terkait dengan rendahnya kualitas pendidikan, kualitas pengajaran dan praktek pengajarannya (Sadtyadi \& Kartowagiran, 2014). Profesi seorang guru mempunyai peran yang sangat vital dalam proses pembelajaran, hal ini bisa dipahami bersama karena seorang guru dapat memberikan bekal pengalaman belajar pertama kepada siswa (Junianti, Hastuti, \& Alfiasari, 2017).

Profesi guru selain sebagai tenaga mengajar, juga memerankan profesi sebagai pengganti orang tua di sekolah. Penanaman sikap yang sekarang sedang diarahkan menjadi titik pusat pembelajaran pada Kurikulum 2013 terbukti bahwa materi yang diarahkan pada sikap mempunyai porsi yang lebih besar dibandingkan dengan pengetahuan. Peran yang dimiliki oleh seorang guru adalah bukan semata-mata memberikan informasi, akan tetapi juga memberi dan mengarahkan 
fasilitas belajar (directing and facilitating the learning) dalam mencapai proses pembelajaran yang efektif (Budiwati, Sumartini, \& Pinayani, 2016). Sebagai profesi, guru juga diharuskan untuk memberikan penilaian sebagai hasil evaluasi suatu proses pembelajaran.

Guru selain mengajar juga dituntut untuk memperbaiki dan mengevaluasi guna tercapainya proses pembelajaran yang efektif (Zulfadli \& Ferryansyah, 2017). Seorang guru dalam melatih dan mengarahkan mempunyai tiga indikator tugas, yaitu memberikan motivasi belajar, memberikan panduan dalam melakukan aktivitas belajar dan membiasakan siswa untuk berperilaku yang positif (Sadtyadi \& Kartowagiran, 2014). Untuk itulah seorang guru harus siap dalam mengajar dan menyesuikan perkembnagan teknologi. Solusi yang dihadirkan melalui pendidikan seharusnya memberikan jawaban sesuai perubahan zaman, pendidikan sebagai solusi harus berorientasi pada era baru masa depan (Abbas, 2013).

Peran guru dalam pendidikan di Papua sangat beragam dan unik. Dikatakan beragam karena semua orang dapat menjadi guru asal mau mengajarkan ilmu, dan unik karena profesi guru yang sering ditemui di kota, tempat mengajarnya di pedalaman. Hal ini yang sering menjadi arahan dari Dinas Pendidikan yang mengharuskan guru yang sudah menerima SK mengajar wajib tinggal di tempat kerja sampai batas libur sekolah tiba. Dari segi implementasi, keadaan pendidikan di Papua masih memerlukan perhatian khusus. Penelitian yang dilakukan oleh Sumarsono (2018) pada guru-guru MI di Kota Merauke, ditemukan bahwa implementasi kurikulum secara keseluruhan berjalan dengan kategori baik, akan tetapi pada standar penilaian masih dijumpai kesulitan dalam pengaturan waktu karena selain mengajar, bersamaan harus melakukan penilaian ranah sikap, pengetahuan dan keterampilan. Melalui keadaan dari kondisi pendidikan yang sudah ada selanjutnya dapat diberlakukan kesimpulan untuk menerangkan keadaan dari kategori kondisi keadaan daerah setempat. Cermin dari keadaan pendidikan di suatu daerah dapat dilihat dari tingkat pendidikannya, semakin tinggi tingkat pendidikan maka akan semakin mudah mengikuti perkembangan ilmu pengetahuan dari kemajuan zaman (Wulandari, 2010).

Pulau Papua yang berada di ujung timur Indonesia mempunyai luas daerah yang terdiri dari pegunungan dan dataran. Letak pulau Papua yang jauh dari Ibu kota negara, maka dapat dinyatakan sebagai pulau terluar. Keberadaan daerah perbatasan Republik Indonesia dengan negara Papua New Guinea (PNG) menunjukkan bahwa terdapat daerah pedalaman yang jauh dari kota. Penyebutan kata pedalaman didapatkan menjadi beberapa wilayah lingkaran, diantaranya wilayah lingkaran pertama untuk wilayah kota, lingkaran kedua wilayah pinggiran, lingkaran ketiga untuk daerah terpencil dan lingkaran keempat adalah daerah terisolasi (Irianto \& Subandi, 2015). Berdasarkan dari lingkaran yang sudah di tentukan bermakna bahwa Kabupaten pemekaran baru di Kabupaten Merauke dan sekitarnya terdapat dalam lingkaran kategori terpencil dan terisolasi. 
Letak geografis Pulau Papua menyebabkan Papua dihuni oleh orang asli Papua dan pendatang yang saling berdampingan dalam mencari dan bertahan hidup. Keadaan pendidikan di Papua memang mempunyai ciri khas dibanding dengan daerah lainnya. Permasalahan pendidikan berdasarkan data hasil riset yang dilakukan oleh Wulandari (2010) bahwa tingkat partisipasi sekolah khususnya di tingkat Sekolah Menengah di Papua sangat rendah khususnya di daerah pedalaman yang mencapai 25,42 ditingkat SMP dan 7,07 ditingkat SMA. Medan yang terjal karena infrastruktur jalan, serta keadaan ekonomi keluarga yang masih belum stabil menjadi penyebabnya.

Keadaan tenaga pengajar di Pedalaman Papua, mempunyai kisah yang dilematis. Keberadaan tenaga guru yang diharapkan mampu menjadi inspirasi bagi siswa terkadang tidak berada di tempat tugas (Fredy, Tembang, \& Purwanty, 2019). Hal ini dikarenakan keberadaan keluarga yang berada di kota. Jauhnya jarak yang harus ditempuh menyebabkan lamanya ke tempat pekerjaan jika pulang ke keluarga. Keadaan tenaga pengajar yang ditempatkan di pedalaman sangat problematis. Sebagai contoh keberadaan tenaga pengajar di Kanada yang menunjukkan sulitnya merekrut dan mempertahankan tenaga pengajar yang berkualitas di pedalaman. Kondisi ini disebabkan karena lebih banyak lulusan yang memilih mengabdi di pusat-pusat kota, ataupun jika ada tenaga pengajar yang bersedia di pedalaman, sifatnya hanya sebagai batu loncatan sebelum kembali ke kota (Barter, 2008).

Fenomena banyaknya tenaga pengajar yang berasal dari pedalaman mengikuti perkuliahan di Jurusan Pendidikan Guru Sekolah Dasar (PGSD) yang berada dibawah naungan Fakultas Keguruan dan Ilmu Pendidikan (FKIP), Univeritas Musamus yang ada di Kabupaten Merauke, Papua adalah salah satu bentuk bukti bahwa arus pendidikan sudah menyadarkan para guru untuk kembali memperbaiki dan memperbarui keilmuan sesuai dengan tuntutan zaman. Penelitian ini secara fokus menguak dan menganalisa motivasi yang mendasari para guru-guru yang berasal dari pedalaman untuk mengikuti proses perkuliahan di Jurusan PGSD Universitas Musamus. Pertanyaan penelitian yang hendak dijawab melalui penelitian ini adalah bagaimana motivasi mengajar guru yang bertugas di pedalaman dan apakah motivasi guru untuk melanjutkan kuliah walaupun sudah berusia lanjut? Pertanyaan tersebut akan menjawab pandangan bahwa guru selain menjalankan profesi mengajar juga mengabdikan diri pada bangsa dan negara melalui jalur pendidikan.

\section{METODE}

Rancangan penelitian ini adalah penelitian kualitatif. Hal ini dikarenakan pengidentifikasian hal yang natural selanjutnya menganalisa hasil tersebut secara deskriptif (Hasbiansyah, 2008). Perspektif yang digunakan sesuai dengan tujuan ini menggunakan fenomenologi yang mengkaji 
tentang motivasi mengajar dan studi lanjut yang telah dilakukan oleh Guru di Jurusan PGSD Universitas Musamus. Subyek yang dilibatkan dalam penelitian ini meliputi lima partisipan yang keseluruhan adalah guru-guru yang telah berusia lanjut dan melanjutkan studi di jurusan PGSD Universitas Musamus.

Sumber data primer dalam penelitian adalah partisipan yang berjumlah lima orang guru dari pedalaman Papua. Pengumpulan data diperoleh melalui wawancara terstruktur dan observasi. Akurasi data dalam penelitian ini adalah (1) bukti lapangan, (2) pendistribusian data terstruktur, (3) akurasi instrumen yang telah menguasai medan dan materi, (4) pelaksanaan apersepsi dari hasil data yang telah dibaca ulang oleh informan dan disetujui sebagai hasil pemaparan hasil penelitian, (5) triangulasi data sebagai klarifikasi dari instansi yang dilibatkan dalam penelitian, serta (6) rujukan sumber referensi yang digunakan sebagai instrumen pendamping dalam evaluasi hasil penelitian. Berdasarkan hasil triangulasi dapat dijabarkan analisis deskripsi dari keberadaan dan fenomena yang muncul dalam pengambilan kesimpulan yang mengikat.

\section{HASIL DAN PEMBAHASAN}

Hasil dari penelitian ini adalah motivasi yang mendasari guru-guru yang berasal dari pedalaman untuk mengajar dan melanjutkan studi pada jenjang Pendidikan Tinggi. Penyajian hasil penelitian diawali dengan deskripsi dari masing-masing individu partisipan yang dilanjutkan dengan temuan sesuai hasil analisa lapangan.

Partisipan 1 Tn. ST usia 55 tahun, berkeluarga, beragama Islam, bertugas di Sekolah Dasar pedalaman Kabupaten Asmat.

Motivasi terbesar dalam melakukan tugas sebagai tenaga pengajar adalah keberadaan keluarga dan pendidikan di sekitar lingkungan. Pengalaman terdahulu pernah dikisahkan tentang pengalaman di masa muda bahwa inspirasi datang dari pemuka agama di daerahnya yang berkata bahwa untuk menjadi benar manusia harus mengenal Tuhan, tetapi untuk menjadi pintar harus mengenal pendidikan. Pendidikan yang berupa ilmu dapat mengentaskan dari belenggu pemikiran yang sangat sempit, melalui pendidikan dapat membuka diri akan perubahan zaman dan dapat berjalan berdampingan dengan perubahan tersebut. Artinya, tidak ada lagi konsep perubahan zaman yang harus di tolak atau tidak sejalan dengan perubahan tesebut.

Partisipan 2 Tn. YJG berusia 58 tahun, berkeluarga, beragama Katolik, bertugas di SD Inpres Tambat, dan sementara sedang melaksanakan tugas belajar ditempatkan di SD YPK Mopah Lama Merauke.

Motivasi yang mendominasi dalam melakukan tugas sebagai tenaga pengajar adalah beban ekonomi yang harus di emban oleh keluarga. Saya adalah anak sulung yang mempunyai lima orang adik. Sedangkan orang tua kami adalah warga masyarakat biasa yang keseharianya hanya 
melakukan kegiatan berburu di hutan. Keadaan ekonomi yang sangat kurang mengharuskan saya untuk bekerja membantu orang tua dalam memenuhi kebutuhan keluarga.

Partisipan 3 Ny. IU berusia 41 tahun, belum berkeluarga, beragama Katolik, bertugas di Sekolah Dasar pedalaman Kabupaten Bouven Digoel.

Berbeda dengan partisipan sebelumnya, Partisipan 3 menyebut bahwa motivasi yang mendorongnya untuk menjadi tenaga pengajar adalah tradisi turun temurun. Pengalaman saudara dari orang tuanya yang menjadi pegawai, membuat orang tuanya mendukung penuh Partisipan 3 untuk juga menjadi pegawai. Harapan orangtuanya terwujud setelah ia berhasil diterima sebagai guru di sekolah dasar di pedalaman. Selain sebagai guru, Partisipan 3 juga pernah menjadi pejabat struktural di lingkungan dinas pendidikan di Kabupaten Bouven Digoel.

Partisipan 4 Tn. SC berusia 46 tahun, sudah berkeluarga, beragama Katolik, bertugas di SD YPPK Suam distrik Tabonji, Penitipan di SD Negeri 1 Merauke.

Motivasi yang mendominasi dalam melakukan tugas sebagai tenaga pengajar adalah tuntutan pendidikan yang pada saat itu mengharuskan untuk melanjutkan sekolah yang lebih tinggi. Hal ini dikarenakan pada lingkungan asalnya sangat jarang ditemui orang yang rela mengorbankan waktunya untuk menuntut ilmu. Hal ini hanya diawali dengan coba-coba karena pada saat itu sekolah masih gratis. Akan tetapi semakin bertambah umur ternyata mengharuskan untuk lulus dan melanjutkan di tingkat lebih tinggi. Adanya fasilitas dari pemerintah mewajibkan partisipan melanjutkan hingga bangku kuliah. Pendidikan di perguruan tinggi yang pernah ditempuh hanya sampai pada Diploma dua, karena pada saat itu jenjang inilah yang paling tinggi yang dapat ditempuh. Selanjutnya, karena lulusan Diploma Dua yang sangat jarang, maka partisipan diminta untuk mengabdi di salah satu sekolah untuk menjadi tenaga pengajar.

Partisipan 5 Ny. MM berusia 50 tahun, sudah berkeluarga, beragama Katolik, bertugas di SD Inpres Mangga Dua Merauke.

Motivasi yang mendominasi dalam melakukan tugas sebagai tenaga pengajar adalah karena kebutuhan akan pekerjaan. Kondisi yang mengharuskan pada waktu itu adalah karena sudah akan menikah dan belum mendapat pekerjaan. Lokasi sekolah yang dekat dengan tempat tinggalnya mengharuskan partisipan untuk bisa mengajar agar dapat mencukupi kebutuhan keluarga. Selama berkecimpung di dunia pendidikan, memunculkan keharusan diri untuk mengikuti peraturan sekolah. Sejak saat itu filosofi sebagai tenaga pengajar juga diikuti dan dilaksanakan.

\section{Motivasi dalam Mengajar}

Jenis motivasi yang mendasari tugas menjadi guru dan mengabdi di daerah pedalaman sama halnya dengan motivasi dalam pembelajaran, yang meliputi dua jenis motivasi, yaitu motivasi intrinsik dan motivasi ekstrinsik (Nuraini, \& Laksono, 2019). Wujud dari motivasi ekstrinsik 
adalah mendapat pekerjaan, mendapat penghasilan dan mendapat status yang diakui oleh tetangga dan saudara terdekat. Sedangkan motivasi intrinsik adalah kesadaran mengabdikan diri pada bangsa dan negara, aktualisasi dari perwujudan nilai-nilai keagamaan, kesadaran sendiri untuk berkontribusi sebagai warga lokal.

\section{Motivasi ekstrinsik}

Pekerjaan adalah bagian dari motivasi ekstrinsik yang diucapkan pertama kali oleh Partisipan 1, 2 dan 4. Alasan pekerjaan dipilih karena guru merupakan profesi yang digaji oleh pemerintah setiap bulan. Keberadaan tempat tinggal di kampung, dimana pekerjaan yang dipilih umumnya mengandalkan hasil alam, membuat ketiga partisipan mendaftar menjadi Guru di Sekolah Dasar.

Pertama sejak muda sa berkeinginan menjadi pejabat, zaman dulu banyak yang suka dengan pergi diantar, dikawal dan naik mobil terus...sejak saat itu sa mau mencari pekerjaan saja...tetapi karena dikampung hanya ada lowongan guru ya akhirnya sa masuk mengajar saja...Tn.ST_a.5)

Mendapat penghasilan tetap adalah motivasi ektrinsik dari partisipan. Hal ini disampaikan hampir oleh tiga partisipan. Keberadaan kampung di pedalaman yang jauh dari hiruk pikuk perputaran uang menyebabkan keinginan untuk mendapatkan penghasilan tetap selain mendapat pekerjaan (Irianto \& Subandi, 2015). Pendapatan tetap menjadi guru berbeda jika dibandingkan dengan pekerjaan lain. Hal ini didasarkan pengalaman yang dilalui ketika menjalani pekerjaan mencari ikan dan daging ke hutan, karena jika tidak dapat maka pulang tidak membawa uang.

“..siapa juga su tau kalau cuma pekerjaan saja di kampung banyak, tapi bekerja sampai capai pun tidak akan mendapat uang gajian tetap..apalagi kitorang butuh beras dan lauk pauk juga to...Tn. YJG_b.4)

Status sosial yang diakui oleh tetangga dan saudara, menjadi motivasi ketiga yang diinginkan oleh salah satu partisipan. Tinggal di kampung yang jauh dari kota, keberadaan pekerjaan yang menetap dapat menjadi pegangan jika berada di lingkungan masyarakat. Menjadi seorang guru, mempunyai pengakuan dari saudara dan juga tetangga menunjukkan bahwa keberadaannya memiliki status sosial yang lebih (Rahadian, 2015; Ashsiddiqi, 2012).

\section{Motivasi Intrinsik}

Motivasi yang mempengaruhi tenaga pengajar untuk melakukan tugas mengajar dari hasil penelitian ini secara garis besar digolongkan menjadi tiga, yaitu mengabdi kepada bangsa dan negara sebagai aktualisasi rakyat Indonesia, implementasi dari nilai agama dan kepercayaan yang dianut untuk bertindak dan bertingkah laku yang dapat bermanfaat bagi orang lain, serta kesadaran pribadi dalam mencerdaskan putra putri Papua yang belum tersentuh pembelajaran. Tiga hal ini yang selalu disampaikan pada saat wawancara dengan partisipan di lapangan. Keberadaan guru ditengah masyarakat menjadi perlu karena tutur kata seorang guru sangat berguna sebagai rujukan dalam menjalani hidup. Sebagai warga lokal Papua yang telah lahir dan besar di lingkungan 
masyarakat lokal, partisipan sangat bangga bisa mengabdikan diri untuk memberi pendidikan kepada masyarakat seperti yang dinyatakan oleh Partisipan 3 dan 5.

"putra-putri kita ini adalah aset yang akan menggantikan kita sebagai orang tua dalam membangun dan melestarikan kehidupan yang semakin baik, untuk itu dorang semua harus sekolah, dorang harus belajar... "Ny IU_c.10)

Selain sebagai tempat pengabdian kepada masyarakat lokal Papua, menjadi guru juga memberikan tempat dalam andil mengabdi kepada negara Indonesia. Kesempatan menjadi guru dapat dimanfaatkan untuk mengenalkan dan memupuk rasa nasionalisme yang sudah dikenalkan sejak usia sekolah (Wuryandani, 2010). Guru yang mengajar di sekolah tidak hanya mengajar materi sekolah saja, akan tetapi dapat dijadikan perwujudan cinta kasih yang diajarkan oleh agama yang dianut untuk dapat membawa kebaikan bagi sesama manusia.

Kitorang ini sampe sekarang rasa ingin segera kembali ketempat tugas besar sekali, karna kalau bukan kita yang datang mengajar, siapa lagi. Dong masyarakat kampung juga manaruh harapan besar kepada kami yang sementara studi lanjut..., MM_e.13)

\section{Motivasi Melanjutkan Studi di Jurusan PGSD}

Selain motivasi dalam mengajar di pedalaman, pada penelitian ini juga dijabarkan alasan yang mendasari dalam bentuk motivasi untuk melanjutkan studi lajut di jurusan PGSD Universitas Musamus Kabupaten Merauke, Papua. Hal inilah yang terus memberikan semangat dari dalam diri guru untuk terus melanjutkan studi sampai dengan lulus wisuda. Berdasarkan dari analisa data hasil penelitian dari sub faktor studi lanjut di Jurusan PGSD dapat dijelaskan sebagai berikut.

Motivasi yang mendominasi dalam melanjutkan studi di jurusan PGSD Universitas Musamus adalah penyesuaian dengan peraturan pemerintah. Hal ini sejalan dengan penelitian sebelumnya yang memberikan gambaran bahwa peraturan pemerintah menjadi alasan guru untuk melanjutkan studi di Perguruan Tinggi (Wardani, 2012; Ruswandi, 2018). Sesuai dengan yang sudah ditentukan bahwa tenaga pengajar wajib minimal berijazah Sarjana (S1) untuk penyelenggaraan pendidikan di sekolah. Peraturan yang sudah disampaikan pada masing-masing dinas Pendidikan dan Kebudayaan ini sudah disosialisasikan. Masing-masing guru diberikan kesempatan yang sama untuk menempuh pendidikan bagi yang belum mempunyai Ijazah S1. Peraturan yang sudah ditetapkan ini selanjutnya diberikan kebijakan oleh Pemerintah Daerah Kabupaten Merauke untuk melajutkan studi dengan keterangan izin dan tugas belajar. Motivasi dari tiga partisipan yang sebelumnya sudah mempunyai ijazah Diploma II, ketiganya mengutarakan bahwa melanjutkan studi perlu dilakukan karena bidang keilmuan yang menunjang dalam mengajar harus selalu diperbaharui dan selalu ditingkatkan. Partisipan 2, 3 dan 5 mengutarakan:

"bagaimana kita mengajar dengan kemampuan kita yang sudah ada sejak zaman dahulu tetapi adek-adek dorang su mengenal teknologi canggih macam di handphone, jadi pak guru harusnya sudah faham duluan tentang informasi tu baru adek-adek, bahaya jika sebaliknya"... 
Maksud dari ungkapan itu dapat diterjemahkan bahwa kecanggihan teknologi, khususnya dalam pendidikan harus juga dikuasai dan dipahami oleh guru, dengan ini nantinya siswa akan mendapatkan informasi yang baru dari guru. Akan terasa sangat tidak sesuai jika siswa nanti malah mengajari guru dalam mengenal kecanggihan teknologi. Untuk itu guru wajib memahami terlebih dahulu informasi yang sudah berkembang (Rosyid, 2016). Selain itu, Partisipan 1 mengutarakan motivasi yang mendominasi dalam melanjutkan studi di jurusan PGSD Universitas Musamus adalah karena alasan keluarga. Mengabdi di pedalaman merupakan tugas yang sudah biasa diemban. Alasan partisipan bersemangat untuk melanjutkan studi di Universitas Musamus karena ia lebih dekat dan bisa berkumpul dengan keluarga. Mengabdikan diri di pedalaman membuat partisipan harus berpisah dengan keluarga, melalui kuliah ini partisipan dapat mendekatkan diri dengan keluarga di kota.

Setiap manusia mempunyai motivasi yang selalu berbed. Hal ini juga diutarakan oleh Partisipan 4 bahwa motivasi yang mendominasi dalam melanjutkan studi di jurusan PGSD Universitas Musamus adalah ingin bisa naik pangkat dan menjadi kepala sekolah. Kesempatan yang sangat baik tidak akan berulang kedua kali. Oleh karena itu, begitu kesempatan itu datang maka harus digunakan sebaik-baiknya. Keberadaan sekolah dasar tempatnya mengajar masih belum mempunyai Kepala Sekolah yang menetap di kampung dikarenakan Kepala Sekolah sebelumnya tidak betah untuk bertahan. Hal ini sangat beralasan, karena medan dan jarak yang sangat jauh untuk mencapai sekolah tersebut.

"kalau saya bisa lulus sarjana dari kampus ini (Universitas Musamus), maka sa bisa urus sa pu pangkat PNS yang selama ini hanya mentok di IIa hingga umur 46 tahun ini. Bisa juga saya berpeluang jadi kepala sekolah to, hahai...”.

Secara garis besar motivasi dari hasil penuturan lima orang partisipan dalam penelitian ini adalah latar belakang yang mendasari pengabdian sebagai guru di pedalaman adalah karena dorongan kesadaran dari dalam diri sendiri (intrinsik). Melalui motivasi ini dapat digunakan sebagai alat pendorong semangat dan aktualisasi diri sebagai tenaga pengajar. Penuturan dari partisipan dapat digambarkan secara singkat pada Gambar 1. 


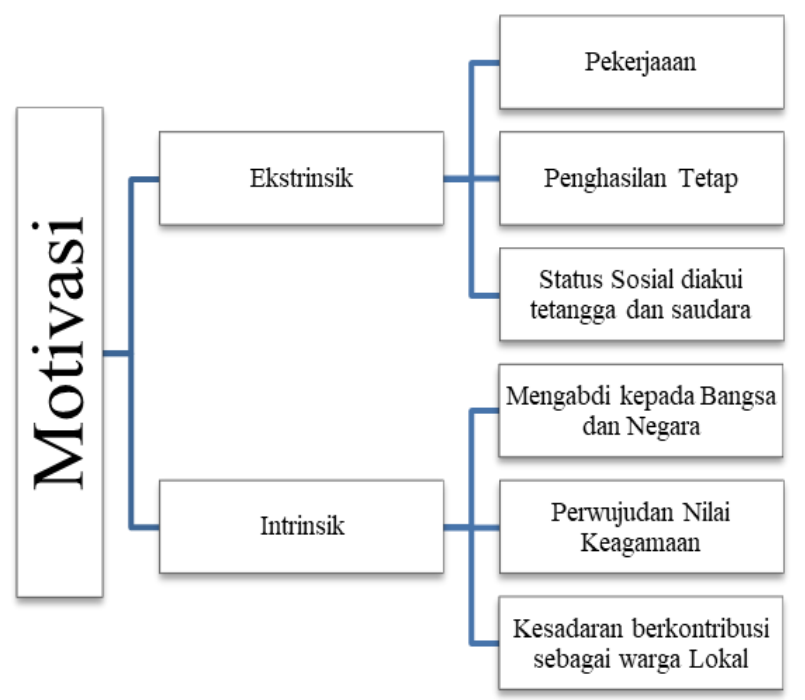

Gambar 1. Motivasi Mengajar Partisipan dalam Penelitian

Gambar 1 menunjukkan bahwa motivasi yang dimiliki oleh partisipan terdiri dari motivasi intrinsik dan ekstrinsik. Motivasi intrinsik terdiri atas: (1) mengabdi kepada bangsa dan negara, (2) perwujudan nilai keagamaan, dan (3) kesadaran berkonstribusi sebagai warga lokal. Motivasi yang berikutnya ialah motivasi ekstrinsik yang terdiri atas: (1) pekerjaan, (2) penghasilan tetap, dan (3) status sosial diakui oleh tetangga dan saudara.

\section{SIMPULAN DAN SARAN}

\section{Simpulan}

Tenaga pengajar yang sudah berumur dan masih tetap bersemangat dalam mengikuti perkuliahan di Jurusan PGSD ternyata mempunyai motivasi yang berbeda-beda. Motivasi dalam memilih dan menentukan pekerjaan menjadi tenaga guru rata-rata sangat banyak dipengaruhi oleh motivasi ekstrinsik daripada motivasi intrinsik. Hal ini dapat dimaklumi, sebab terkait dengan persaingan dalam mendapat pekerjaan. Motivasi yang masih kuat dan dominan dalam menempuh mata kuliah dan bersemangat menyelesaikan studi lebih dipengaruhi oleh faktor dari luar. Alasan kuat dalam faktor dari luar ini dikarenakan umur partisipan yang sudah tua dan kesempatan dalam mendalami ilmu masih kalah dibandingkan dengan mencapai keberhasilan dalam memperoleh ijazah S1 dari Universitas Musamus.

\section{Saran}

Guru di pedalaman ikut andil dalam memajukan pendidikan melalui perkembangan keilmuan yang sesuai perkembangan zaman. Majunya pola piker guru akan berdampak pada pola piker siswa dan masyarakat untuk terus bergerak maju. Hasil penelitian ini menunjukkan bahwa faktor mendapatkan kesejahteraan adalah motivasi terakhir bagi guru dalam mengajar dan melanjutkan studi. Hal ini menunjukkan sudah terpatri pada diri setiap guru untuk mengabdi sebagai pahlawan 
tanpa tanda jasa. Oleh karena itu, perlu adanya apresiasi dari pemerintah pusat, daerah, maupun masyarakat sekitar, misalnya dalam bentuk regulasi atau bantuan secara moril, untuk terus memajukan kualitas serta kesejahteraan guru, khususnya di pedalaman Papua.

\section{DAFTAR PUSTAKA}

Abbas, I. (2013). Pappaseng: Kearifan Lokal Manusia Bugis yang Terlupakan. Jurnal Sosiohumaniora, Vol. 15 No.3, 273.

Ashsiddiqi, H. (2012). Kompetensi sosial guru dalam pembelajaran dan pengembangannya. Ta'dib: Journal of Islamic Education (Jurnal Pendidikan Islam), 17(01), 61-71.

Barter, B. (2008). Rural Education: Learning to be Rural Teachers. Journal of workplace Learning Vol 20. No. 8, 468-479.

Budiwati, N., Sumartini, \& Pinayani, A. (2016). Tantangan Profesionalisme dan Kesiapan Guru Mengimplementasikan Kurikulum 2013. Jurnal Ekonomi Pendidikan dan Kewirausahaan Vol. 4 No. 1, 93.

Fredy, F., Tembang, Y., \& Purwanty, R. (2019). Analisis Kepuasan Orangtua dan Siswa terhadap Kualitas Layanan Pendidikan Dasar. Musamus Journal of Primary Education, 59-66.

Hasbiansyah, O. (2008). Pendekatan Fenomenologi: Pengantar Praktik Penelitian dalam Ilmu Sosial dan Komunikasi. Mediator: Jurnal Komunikasi, 9(1), 163-180.

Hurit, A. A., \& Harmawati, D. (2019). Analisis Kesiapan Guru dalam Mengimplementasikan Kurikulum 2013 di SD Inpres Gudang Arang Merauke. Musamus Journal of Primary Education, 116-123.

Irianto, \& Subandi. (2015). Studi Fenomologis Kebahagiaan Guru di Papua. Gajah Mada Journal of Psychology Vol. 1 No.3, 142.

Junianti, M. Y., Hastuti, D., \& Alfiasari, A. (2017). Analisis Sosialisasi Akademik dan Motivasi Berprestasi Anak Usia Sekolah pada Keluarga di Pedesaan. Sekolah Dasar: Kajian Teori dan Praktik Pendidikan, 25(1), 1-11.

Kemdikbud. 2012. Permendikbud No. 34 Tahun 2012. Jakarta: Kemdikbud

Musanna, A. (2012). Artikulasi Pendidikan Guru Berbasis Kearifan Lokal untuk Mempersiapkan Guru yang Memiliki Kompetensi Budaya. Jurnal Pendidikan dan Kebudayaan Vol. 18 No. 3,339 .

Nggaruaka, T., Hermansyah, A. K., \& Sauhenda, A. F. (2019, October). Collection and administration of regional stories (oral literature of riantana's travel for saving the khazana culture of papua). In IOP Conference Series: Earth and Environmental Science (Vol. 343, No. 1, p. 012236). IOP Publishing.

Nuraini, N. L. S., \& Laksono, W. C. (2019). Motivasi Internal dan Eksternal Siswa Sekolah Dasar pada Pembelajaran Matematika. Sekolah Dasar: Kajian Teori dan Praktik Pendidikan, 28(2), 56-64.

Pambudi, R. E. (2017). Implementasi Sustainable Development Goals. eJournal Ilmu Hubungan Internasional Vol. 5 No. 3, 919.

Pemerintah. 2003. Undang-Undang No. 20 Tahun 2003 tentang Sistem Pendidikan Nasional. Jakarta: Pemerintah Republik Indonesia

Pemerintah. 2005. Undang-Undang No. 14 Tahun 2005 tentang Guru dan Dosen. Jakarta: Pemerintah Republik Indonesia

Rahadian, D. (2015). Peran Dan Kedudukan Guru Dalam Masyarakat. Jurnal Petik, 1(1), 26-37. 
Rosyid, A. (2016, Agustus). Technological Pedagogical Content Knowledge: Sebuah Kerangka Pengetahuan Bagi Guru Indonesia di Era MEA. In Prosiding Seminar Nasional Inovasi Pendidikan.

Ruswandi, A. (2018). Motivasi Mahasiswa Usia Dewasa Mengikuti Perkuliahan pada Program Studi Pendidikan Guru Paud di FKIP Uninus Bandung. Jurnal PG-PAUD Trunojoyo: Jurnal Pendidikan dan Pembelajaran Anak Usia Dini, 5(2), 75-85.

Sadtyadi, H., \& Kartowagiran, B. (2014). Pengembangan Instrumen Penilaian Kinerja Guru Sekolah Dasar Berbasis Tugas Pokok dan Fungsi. Jurnal Penelitian dan Evaluasi Pendidikan, 291.

Selvi, K. (2010). Teachers' competencies. Cultura International Journal of Philosophy of Culture and Axiology, 7(1), 167-175.

Siram, R. (1995). Pengembangan Kurikulum Muatan Lokal Tingkat Sekolah Menengah Umum di Kalimantan tengah. Jurnal Ilmu Pendidikan, 340.

Sumarsono, A. (2018). Persepsi Guru Madrasah Ibtidaiyah (MI) dalam Menerapkan Kurikulum 2013 di Kabupaten Merauke. Al-Islah Jurnal Pendidikan Vol. 10. No. 2, 156.

Tembang, Y., Sulton, S., \& Suharjo, S. (2017). Peningkatan motivasi dan hasil belajar melalui model pembelajaran think pair share berbantuan media gambar di sekolah dasar. Jurnal Pendidikan: Teori, Penelitian, dan Pengembangan, 2(6), 812-817.

Tilaar, H. A. (2012). Management Proses peningkatan Mutu Pendidikan di Pulau Terpencil Kasus Peningkatan . Riset kebijakan Pendidikan Anak di Indonesia (hal. 237). Tangerang: Kementerian Pendidikan dan Kebudayaan UNICEF Indonesia.

Wardani, I. G. (2012). Mengembangkan Profesionalisme Pendidik Guru (Kajian Konseptual Dan Operasional). Jurnal Pendidikan, 13(1), 32-44.

Wulandari, D. (2010). Research on the education sector in papua communities, children and teachers in papua hand in hand for a better future. Journal West Papua Published by Justice And Peace Netherlands, 2.

Wuryandani, W. (2010). Integrasi nilai-nilai kearifan lokal dalam pembelajaran untuk menanamkan nasionalisme di sekolah dasar. In Proceding seminar nasional lembaga penelitian $U N Y$ (pp. 1-10).

Zulfadli, \& Ferryansyah. (2017). Pelatihan dan Bimbingan Pembuatan Karya Tulis Ilmiaha Berbasis Penelitian Tindakan Kelas (PTK) di SD Muhammadiyah 1 Tarakan. Jurnal Pengabdian Mayarakat Borneo Vol. 1 No. 1, 41. 